working within the voice hearers' own theories (mystical, transpersonal, metaphysical, reincarnation, parapsychological). Although passing reference is made to studies of some of the cognitive--behavioural approaches, the rest of this section relies for its evidence base on occasional case histories

Overall, this is an intriguing and readable book, which opens up new ways of making sense of voices. It will be of interest to anyone working in the field However, I would not recommend it to an inexperienced practitioner as a handbook.

Philippa Garety

\title{
miscellany
}

\section{The International Society for Affective Disorders}

The International Society for Affective Disorders (ISAD) is a society of scientists, from any discipline or country, who are active in the field of affective disorders research. The basic requirement to qualify for membership is authorship of articles on affective disorders that have been published in peer reviewed journals. The membership includes those working in a scientific capacity in universities, hospitals, industry and other settings. ISAD operates a policy of mutual respect for different scientific approaches to the investigation of the affective disorders, providing they remain within an evidencebased framework. Members will receive the Journal of Affective Disorders as part of their membership and gain access to the network of researchers through the organisation's website (http://www. isad. soton.ac.uk). When fully operational the site will contain an open access section for information to the public and for announcements. There is currently no conference that focuses solely on research into the affective disorders from all disciplines and brings together recent research findings on a yearly or biennial basis. The first meeting is being planned for 9-13 March 2002 in Sicily. For more information on how to join ISAD please contact David K. Beck, Director and Administrator, The International Society for Affective Disorders, Professional Education \& Training Unit, Mental Health Group, University of Southampton, Royal South Hants Hospital, Southampton SO14 OYG (tel: 0238082 5543; e-mail: isadsoton.ac.uk).

\section{Burden Research Prize}

The Burden Research Prize is awarded by the Burden Trust every 3 years for outstanding research work in the field of learning disabilities. This year the prize of $£ 1000$ has been awarded to Dr Jeremy Turk, Senior Lecturer in Child and Adolescent Psychiatry at St George's Hospital Medical School for his research on fragile $\mathrm{X}$ syndrome.

\section{The Great Britain Sasakawa Foundation Butterfield Awards for UK-Japan Medical Research}

The Great Britain Sasakawa Foundation was established in 1985 to further understanding and cooperation between the peoples of Japan and the UK in the fields of culture and society. Lord Butterfield of Stechford, a former Trustee, Chairman and Patron of the Foundation, was a distinguished medical researcher, clinician and administrator. His connections with Japan were close and as a lasting commemoration of his death in July 2000, it was decided to introduce the Butterfield Awards. In principle, three awards of $f 5000$ are offered annually, or a total annual commitment of $f 15000$. Proposals for continuous funding of up to f5000 per annum for a maximum of 3 years are acceptable. There are no absolute restrictions on the field of research, provided that it is one in which the UK and Japan have a mutual and beneficial interest, for example the genetic aspects of ageing; geriatric medicine; palliative care; child and adolescent mental health; or community health care. Applications can be accepted by 31 December 2001 for awards to be made in the second half of 2002. For further information regarding eligibility and other conditions for these awards, and for obtaining application forms, please contact The Great Britain Sasakawa Foundation, 43 North Audley Street, London W1K 6WH (tel: 0207355 2229; fax: 0207355 2230; e-mail: gbsfgbsf.org.uk; website: http://www.gbsf.org.uk).

\section{forthcoming events}

The 9th Conference of the Society of Expert Witnesses will take place on 12 October 2001 in Sheffield. The conference will look at human rights issues and the expert witness and will offer a mix of formal presentations and associated workshops. The Society of Expert Witnesses is the largest expert witness association in the UK. As an independent, non-commercial association, it provides a forum for experts from all disciplines and offers members practical support on the various aspects of providing expert services. For further information about the conference or the Society of Expert Witnesses please contact Teresa Baron, Society of Expert Witnesses, PO Box 345 , Newmarket CB8 7RB (tel: 0845702 3014).

The Institute of Mental Health Law would like to announce the following courses:
Human Rights Act - 1 year on Health, Mental Health and Community Care, which takes place on 20 November 2001, will bring together some of the leading players and will provide an examination of the cases that have been heard, a look at those in the pipeline and anticipation of further impact; Victims: Their Status, Role and Function in Criminal Justice and Mental Health Policy, which takes place on 21 November 2001, will look at a series of topics including compensation for victims, the right to information $v$. patient confidentiality and the White Paper on mental health reform; The Human Rights Act and Mental Health Practice, which takes place on 12 December 2001, will provide an introduction to the Human Rights Act 1998. All three courses will be held in central London and qualify for continuing professional development points. For further information please contact The Institute of Mental Health Law, PO Box 5721, Belper, Derbyshire DE56 2YU (tel/fax: 01773 550900; e-mail: tracyofficemagic. co.uk).

The Division of Psychological Medicine at The Institute of Psychiatry would like to announce The Second Annual Institute of Psychiatry 'Matter-to-Mind'

Symposium. This year's symposium, titled Bipolar Affective Disorder - From Matter to Mind will focus on bipolar affective disorder and builds on the success of last year's meeting, Schizophrenia - 'From Matter to Mind'. The Matter to Mind title reflects the integration of work from all disciplines in academic neuroscience focusing on areas at the cutting edge of research. Leading international psychiatrists will be presenting their current research in bipolar affective disorder. This 
2-day symposium will take place on 27-28 November 2001 at the Institute of Psychiatry in London. For further information please visit http://www.iop.kcl.ac.uk/matter2mind or contact Mike Travis (tel: 0207848 0625; e-mail: m.travisiop.kcl.ac.uk) or Mary Phillips (email: m. phillipsiop.kcl.ac.uk).

The University of Oxford Centre for Evidence-Based Mental Health would like to announce the following events. The 6 th Workshop on Practising EvidenceBased Mental Health will be held at Merton College, Oxford, on 3-5 April 2002. This workshop will demonstrate how evidence-based medicine can help in making clinical decisions concerning diag nosis, treatment, prognosis and harm; it will also equip participants with the basic skills necessary to apply the principles of evidence-based mental health; the strategies covered will include: searching for and critically appraising evidence and using research findings in everyday clinical practice. The MRC Psych Part II Critical Review Paper Preparation will take place in Oxford in February or March 2002 (date to be confirmed) and is specifically aimed at those people who are preparing to take the MRCPsych Part II exam; this course focuses on the skills necessary to take the critical review paper part of the exam and will enable participants to work through a range of past papers and other model papers, using a combination of small groups and lectures. Further details about both events and online registration can be obtained from the following website: http:// www.cebmh.com/mrc2002.html. Alternatively, please telephone Mr Andre Tomlin, Director of Knowledge Services, Centre for Evidence-Based Mental Health,
Department of Psychiatry, on: 01865 223785.

Mole Conferences would like to announce the following conferences: Attention Deficit Hyperactivity Disorder (ADHD) in Adult Life: Do they really grow out of it? A 1-day conference being held in London on 9 November 2001, among other issues concerning ADHD this conference will look at case studies, the transition from child to adult services via adolescence, treatment options and the implications of untreated ADHD.

Psychotherapy - Illusion, Thinking and Belief is a 1-day practitioner masterclass that will take place in London on 10 November 2001. Forthcoming conferences include Diagnosis (March 2002), SelfHarm (Spring 2002) and Learning Disability (March 2002). For further information about all the above events please contact: Mole Conferences, 26 Church Road, Portslade, Brighton BN41 1LA (tel: 01273 242 634; fax: 01273235 095; e-mail: infomole-conferences.com; website: http://www.mole-conferences.com).

The Sri Lankan Psychiatric Association (UK) would like to announce the following event being held in Colombo, Sri Lanka, on 4-7 April 2002: International Conference on Mental Health and Psychiatry - Recent Developments in Community Psychiatric Practice. Hosted by the National Council for Mental Health in Sri Lanka and supported by a number of other, both government and non-government, agencies, this conference will provide an opportunity for mental health professionals, academics and policy makers from Sri Lanka, the Asian region and the rest of the world to discuss emerging problems, recent devel- opments and the future challenges in community mental health. For further details please contact the National Council for Mental Health, 96/20 Kitulwatte Road, Colombo 8, Sri Lanka (tel: +94 1 685 960; fax: +94 75 350819; e-mail: sahanayapanlanka.net).

Problem Solving and Offenders is the title of a 1-day national conference taking place on 19 October 2001 at the Royal Moat House Hotel in Nottingham. In this conference, which is jointly organised by Nottinghamshire Healthcare NHS Trust and Cardiff University, academics will explore the nature of offenders' problemsolving deficits, programme authors will describe the content and effectiveness of their treatment programmes and programme facilitators will tell us how they implement programmes. For further details and application forms please contact Veronica Mahony, Professional Education Department, Rampton Hospital Authority, Retford, Nottinghamshire DN22 OPD (tel: 01777247 550; e-mail: veronica.mahonyrampton-hosp.trent. nhs.uk).

The International Attachment Network are the organisers of From Research to Clinical and Related Settings, a series of seminars informing people about research findings and its relationship to application and practice in a variety of settings. The seminars will take place at The Tavistock Institute in London during October, November and December 2001 (weekly sessions on Tuesdays). For further information please contact The International Attachment Network, I Fairbridge Road, London N19 3EW (tel/fax: 020 7281 4441; e-mail: ianattachment. fsnet.co.uk). 